\title{
A Access on Consumer Satisfaction of Hero Two Wheeler Bikes
}

\author{
SP. Karuppiah, Surenthran David P
}

\begin{abstract}
This study is based on the level of consumer satisfaction for bike users in Chennai city of Tamilnadu. The survey is mainly focused on the factors in which the bike owners are satisfied / dissatisfied with two wheeler bikes they are using. Customers play a major role in this competitive era. In order to survive, a company should analyze different factors of consumer satisfaction. Even though it varies from each and every individual, important basic attributes should be identified.

Keywords---- satisfaction, factors, consumer, buying behavior, two wheeler, respondents etc.
\end{abstract}

\section{INTRODUCTION}

The growth of two wheeler industry is manifold around the world over a period of time. In India, two wheeler industry has grown rapidly after the liberalization. Now India is the largest manufacturer and home to largest number of two wheelers in the world. Geared scooters dominated the market until 1990 and now the preference had changed to motorcycles and high end scooters. Since two wheelers are convenient for the Indian families, the first preference of mobility goes to two wheelers. Before few years, only few models were available when compared to the recent years. Hero MotoCorp is the world's leading manufacturer of two wheelers and contributes to $46 \%$ of share in the Indian market. Companies like Yamaha, Honda and Kawasaki have collaboration with Indian companies. Earlier 100cc bikes were popular among the customers, since it is fuel efficient. But now the customers are expecting two wheelers with engines of higher volume. Introducing electric vehicles in the industry is the latest trend which will be the preference of the customers for the next generation.

"Satisfaction is a person's feelings of pleasure or disappointment resulting from comparing a product's perceived performance in relation to his or her expectation".As the definition makes it clear, satisfaction is a function of perceived performance and expectations. The customers are dissatisfied when their expectations are not met and they are delighted if the performance exceeds their expectations. Customer satisfaction helps a company to improve their products and services. Data collected from customer satisfaction can help in evaluating products and services. Based on this data necessary changes can be done in products and services to meet the standards. In order to retain the customers most of the companies aim for highly satisfied customers. If not customers will switch to other

\footnotetext{
Revised Manuscript Received on September 10, 2019.

SP. Karuppiah, Assistant Professor, Department of MBA, St.Joseph's College of Engineering,Chennai, Tamilnadu, India.

(Email: karups2013@gmail.com)

Surenthran David P, Assistant Professor, Department of MBA, St.Joseph's College of Engineering,Chennai, Tamilnadu, India.

(Email: david.mbasjce@gmail.com)
}

company for a better offer. High customer satisfaction leads to the profitability of the business.

\section{OBJECTIVES OF THE STUDY}

- $\quad$ To study the level of customer satisfaction of Hero two wheelers

- To understand the customer attitude towards after sales and services provided by the dealer

- To find out the customer 's opinion as warranty services provided by the dealer

- To ascertain the sources of influences in the purchasing decision of the customers

\section{REVIEW OF LITERATURE}

Dr.N.Chandrasekaran conducted surveys based on the behavior of consumers to investigate the customer wants. Variables like price and product features are considered for this study and it helped to analyze the preference of the consumer towards a specific brand and the difficulties faced by the consumers on using these brands.

Dr.S.K.Sinha\&Ajay Wagh examinedthe telecommunication markets of this century. India a leading telecommunication market with customers like common man, professionals, business man, doctors, engineers, artisans use the services of telecom industry in a huge manner. By understanding the customers preference, the industries in telecom can tap a huge potential in the telecom market and boost the number of customers as well as their profits.

According to Lewis \&Boom measured the service quality based on customer expectations. Customers should be provided a service beyond their expectations. Innovative products, value friendly packages, quality after sales service and cheaper cost should be provided to the customers.

Dr. C. Annandan\&M.Prasanna Mohan Raj \&Mr.S.Madhu conducted programs on marketing in rural market segments which are unexplored. Since the consumption is considerably low in rural areas, FMCG companies can use this opportunity to tap the rural market for better business and performance. Since the central government is focussing on rural areas, more number of companies can understand the rural market and establish their products and services for better profitability.

Rachel Dardis, HoracioSoberon-Ferrer examined that consumer preferences are based on multiple factors like product and house hold attributes. If the cost index value is 
higher, the more unsatisfactory the car is relative to other cars. Educated households have a better knowledge of the performance of Japanese cars and they have a high affinity towards cars of higher value reliability.

\section{RESEARCH METHODOLOGY}

\section{Research Design}

In conformance with the objectives of the study a survey was conducted in Chennai city and based on the findings inferences are given. The study is based on primary data which is collected from customers. Secondary data consists of data collected from various journals, publications and internet.

\section{Data Collection Method}

The researcher had adopted for the study in order to collect from primary sources. A structured questionnaire was designed for collection of primary data. In order to avoid the bias and dislike during data collections, personal interview method was also adopted.Non-probabilistic and convenience sampling method was used to select the respondents. Size of the sample selected for the study was 200.Percentage method, Chi square method, Anova method and Mean score method are used to analyze the data

\section{ANALYSIS AND INTERPRETATION \& RESULTS}

Classification of respondents by age

\begin{tabular}{|l|l|l|}
\hline Age & $\begin{array}{l}\text { No of } \\
\text { Responden } \\
\text { ts }\end{array}$ & $\begin{array}{l}\text { Percentage( } \\
\%)\end{array}$ \\
\hline $\begin{array}{l}\text { Belo } \\
\text { w 20 } \\
\text { years }\end{array}$ & 18 & 9 \\
\hline $\begin{array}{l}\text { 20-30 } \\
\text { years }\end{array}$ & 92 & 46 \\
\hline $\begin{array}{l}30-40 \\
\text { Year }\end{array}$ & 60 & 30 \\
s & & \\
\hline $\begin{array}{l}\text { Abov } \\
\text { e 40 } \\
\text { Year } \\
\text { s }\end{array}$ & 30 & 15 \\
\hline Total & 200 & 100 \\
\hline
\end{tabular}

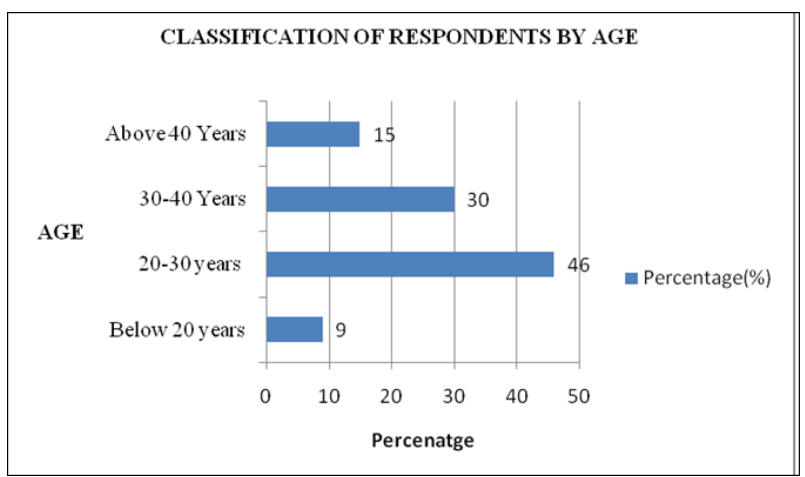

\section{Inference}

It is clear that from the above table that $55 \%$ of the respondents belong to the age group of less than 30 years. $30 \%$ of the respondents belong to the age group of 30-40 years and the remaining $15 \%$ of them are more than 40 years old .

Classification of Respondents by occupation

\begin{tabular}{|l|l|l|}
\hline Occupation & $\begin{array}{l}\text { No of } \\
\text { Respondents }\end{array}$ & Percentage \\
\hline Students & 21 & 10.5 \\
\hline Employees & 94 & 47 \\
\hline Business & 55 & 27.5 \\
\hline Others & 30 & 15 \\
\hline Total & 200 & 100 \\
\hline
\end{tabular}

CLASSIFICATION OF RESPONDENTS BY OCCUPATION

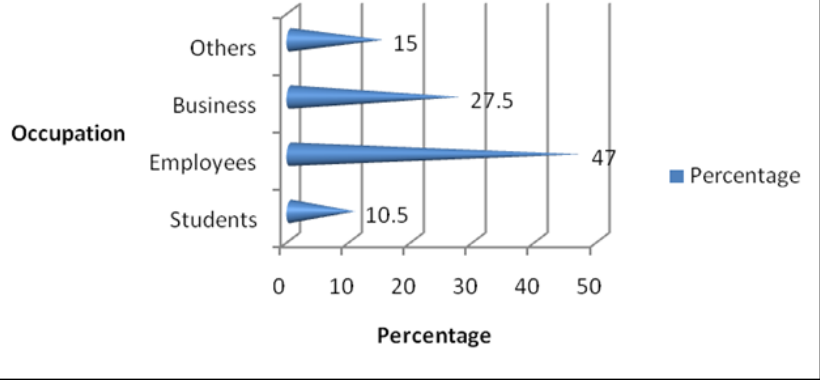

\section{Inference}

The above table shows that $47 \%$ of the respondents are employees followed by the businessman who account for $27.5 \%$, only $10.5 \%$ of respondents are students. It can be inferred that majority of the respondents are employees working in various organizations.

Classification of respondents on the basis of monthly income

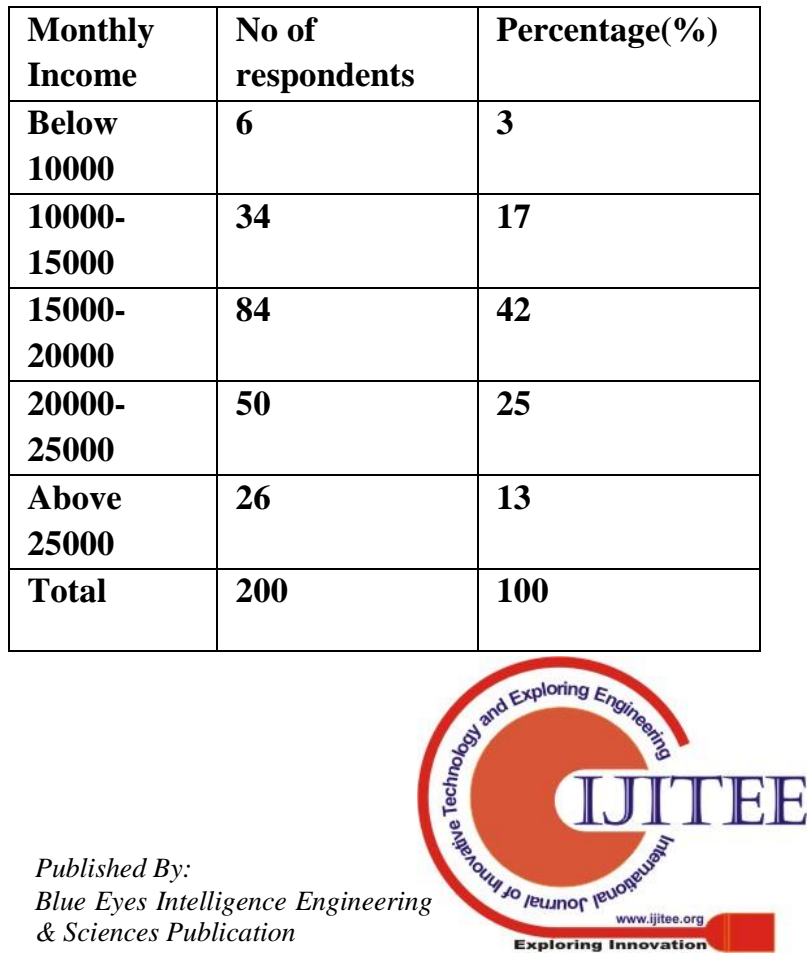




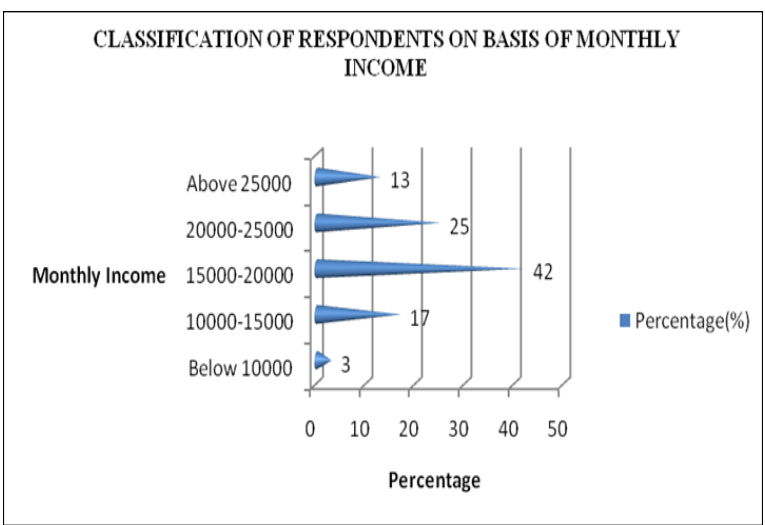

\section{Inference}

It is obvious from the table that $42 \%$ of the respondents belong to the income range of Rs-15000-20000/per month , $25 \%$ of the respondents belong to the income range of $20000-25000 /$ per month followed by $17 \%$ of the respondents belong to the income range of Rs10000$15000 /$ per month. Further only $3 \%$ of the respondents belong to the income of less than Rs10000/per month and $13 \%$ of the respondents belong to the income more than 25000/per month.

Number of respondents based on Vechicle Models

\begin{tabular}{|l|l|l|}
\hline Models & $\begin{array}{l}\text { No of } \\
\text { respondents }\end{array}$ & Percentage(\%) \\
\hline Xpulse 200 & 60 & 30 \\
\hline Splendor & 35 & 17.5 \\
\hline Passion & 30 & 15 \\
\hline $\begin{array}{l}\text { Super } \\
\text { Spendor } \\
\text { IBS }\end{array}$ & 25 & 12.5 \\
\hline Duet & 25 & 12.5 \\
\hline Pleasure & 25 & 12.5 \\
\hline Total & 200 & 100 \\
\hline
\end{tabular}

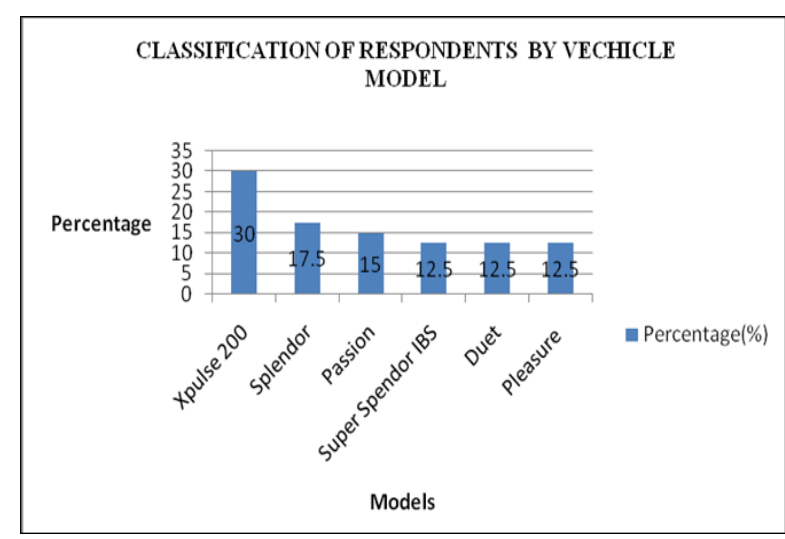

\section{Inference}

The above table shows that $47.5 \%$ of the respondents have xpluse 200 ,Splendor M Models.27.5\% of the respondents have passion, super spendor IBS and the remaining 25\% Of them have duet, Pleasure Models

Source of influence in purchase of vechicles

\begin{tabular}{|l|l|l|}
\hline Factors & $\begin{array}{l}\text { No of } \\
\text { Respondents }\end{array}$ & $\begin{array}{l}\text { Percentage } \\
(\%)\end{array}$ \\
\hline $\begin{array}{l}\text { Family } \\
\text { Members }\end{array}$ & 55 & 27.5 \\
\hline Friends & 40 & 20 \\
\hline Mechanic & 15 & 7.5 \\
\hline Advertising & 60 & 30 \\
\hline $\begin{array}{l}\text { Individual } \\
\text { Decision }\end{array}$ & 30 & 15 \\
\hline Total & 200 & 100 \\
\hline
\end{tabular}

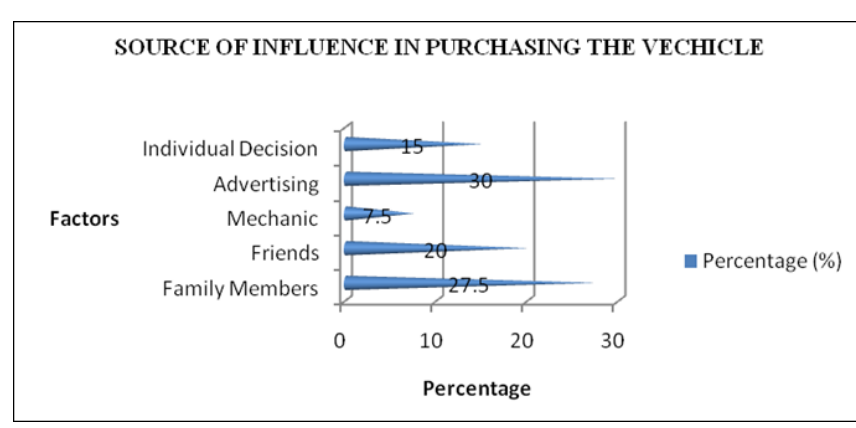

Inference

The above table reveals that $30 \%$ of the respondents are influenced by advertising, $27.5 \%$ of the respondents whose purchasing decision is influenced by family member's influences, $20 \%$ of the respondents are influenced by friends, $15 \%$ of the respondents are influenced by individual decision and $7 \%$ of the respondents are influenced by mechanic.

Customer opinion about their vehicle Mileage

\begin{tabular}{|l|c|c|c|c|c|c|}
\hline Ratings & $\mathbf{5}$ & $\mathbf{4}$ & $\mathbf{3}$ & $\mathbf{2}$ & $\mathbf{1}$ & \\
\hline Model & Very go0d & Good & Average & Below average & Poor & Total \\
\hline Xpulse200 & 40 & 14 & 6 & & & 60 \\
\hline Splendor & 12 & 13 & 10 & & & $\mathbf{3 5}$ \\
\hline Passion & & & 10 & 10 & 10 & 30 \\
\hline $\begin{array}{l}\text { Super Spendor } \\
\text { IBS }\end{array}$ & & 15 & 10 & & & 25 \\
\hline Duet & 10 & 10 & $\mathbf{5}$ & & & 25 \\
\hline Pleasure & 15 & 10 & & & & 25 \\
\hline
\end{tabular}

Mean score analysis for finding the rank of the mileage

\begin{tabular}{|l|r|}
\hline Model & Total \\
\hline Xpulse 200 & $40^{*} 5+14^{*} 4+6^{*}:$ \\
\hline Splendor & $12^{*} 5+13^{*} 4+10^{*}$ \\
\hline Passion & $10^{*} 3+10^{*} 2+10^{*}$ \\
\hline Super SpendorIBS & $15^{*} 4+10^{*} 390$ \\
\hline Duet & $10^{*} 5+10^{*} 4+5^{*}:$ \\
\hline Pleasure & $15^{*} 5+10^{*} 411$ \\
\hline
\end{tabular}




\section{Inference}

The above analysis reveals that as far as mileage is concerned, Pleasure model is ranked I followed by Xpulse 200, Duet, Splendor, Super Spendor IBS, Passion respectively.

Customer opinion about their vehicle Maintenance

\begin{tabular}{|l|c|c|c|c|c|c|}
\hline \multicolumn{1}{|c|}{ Ratings } & $\mathbf{5}$ & 4 & $\mathbf{3}$ & $\mathbf{2}$ & 1 & \\
\hline \multicolumn{1}{|c|}{ Model } & Very g00d & G0od & Average & Below average & P0or & Total \\
\hline Xpulse200 & 40 & 14 & 6 & & & 60 \\
\hline Splendor & 12 & 13 & 10 & & & 35 \\
\hline Passion & 10 & 10 & & 10 & & 30 \\
\hline $\begin{array}{l}\text { Super Splendor } \\
\text { IBS }\end{array}$ & & 15 & 10 & & & 25 \\
\hline Duet & 10 & 10 & & 5 & & 25 \\
\hline Pleasure & 15 & & 10 & & & 25 \\
\hline
\end{tabular}

Mean score analysis for finding the rank of the maintenance

\begin{tabular}{|l|l|c|c|}
\hline \multicolumn{1}{|c|}{ Model } & \multicolumn{1}{c|}{ Total } & Average & Rank \\
\hline Xpulse200 & $40^{*} \mathbf{5}+14^{*} 4+6^{*} 3274$ & 4.56 & I \\
\hline Splendor & $12^{*} \mathbf{5}+13^{*} 4+10^{*} 3142$ & 4.05 & III \\
\hline Passion & $10^{*} 5+10^{*} 4+10^{*} 3120$ & 4 & IV \\
\hline Super SplendorIBS & $15^{*} 4+10^{*} 390$ & 3.6 & VI \\
\hline Duet & $10^{*} 5+10^{*} 4+5^{*} 2100$ & 4 & IV \\
\hline Pleasure & $15^{*} 5+10^{*} 3105$ & 4.2 & II \\
\hline \hline
\end{tabular}

\section{Inference}

The above analysis reveals that as far as maintenance is concerned is Xpulse 200 model is ranked I followed by Pleasure, Splendor, Passion, Duet and Super splendor IBS with rank respectively.

\section{Customer Opinion of Brand Image}

\begin{tabular}{|l|l|l|}
\hline \multicolumn{1}{|c|}{ Ratings } & \multicolumn{1}{|c|}{$\begin{array}{c}\text { No of } \\
\text { Respondents }\end{array}$} & \multicolumn{1}{c|}{$\begin{array}{c}\text { Percentage } \\
\text { (\%) }\end{array}$} \\
\hline Very Good & 80 & 40 \\
\hline Good & 60 & 30 \\
\hline Average & 55 & 27.5 \\
\hline Below & 5 & 2.5 \\
\hline Average & & - \\
\hline Toor & - & 100 \\
\hline
\end{tabular}

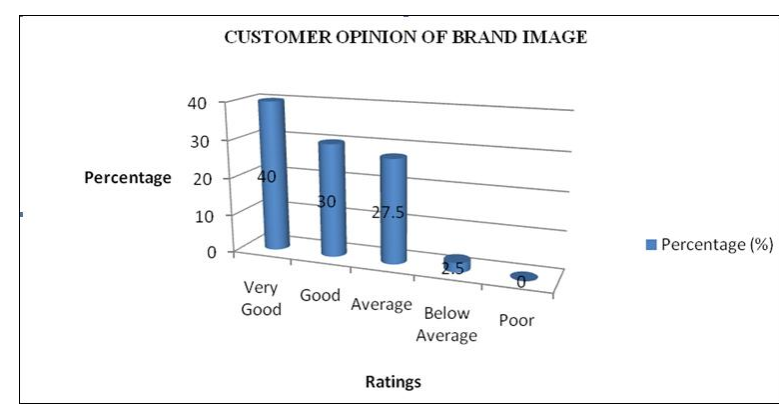

\section{Inference}

The above table shows that $40 \%$ of the respondents are of the opinion that Hero has Very good brand image and 30\% of them considered the brand image as good only and $55 \%$ of the respondents think the brand is average.

Customer satisfaction on performance of the vehicle

\begin{tabular}{|l|l|l|}
\hline $\begin{array}{l}\text { Categor } \\
\mathbf{y}\end{array}$ & $\begin{array}{l}\text { No of } \\
\text { Respondent } \\
\text { s }\end{array}$ & $\begin{array}{l}\text { Percentag } \\
\text { e }(\%)\end{array}$ \\
\hline Satisfied & 167 & 83.5 \\
\hline $\begin{array}{l}\text { Dis- } \\
\text { satisfied }\end{array}$ & 33 & 16.5 \\
\hline Total & 200 & 100 \\
\hline
\end{tabular}

CUSTOMER SATISFACTION ON PERFORMANCE OF THE VEHICLE

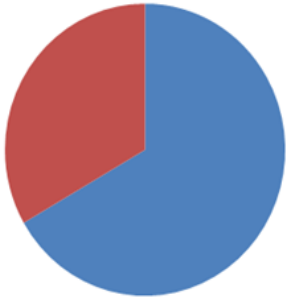

- No of Respondent

- Percentage $(\%)$

\section{Inference}

It is clear that the above table that $83.5 \%$ of the respondents is satisfied with the performance of their vehicles and only $16.5 \%$ of them are dis-satisfied.

Customer Satisfactionon warranty service

\begin{tabular}{|l|c|c|}
\hline \multicolumn{1}{|c|}{ Category } & $\begin{array}{c}\text { No of } \\
\text { Respondents }\end{array}$ & $\begin{array}{c}\text { Percentage } \\
(\%)\end{array}$ \\
\hline Satisfied & 168 & 84 \\
\hline $\begin{array}{l}\text { Dis- } \\
\text { satisfied }\end{array}$ & 32 & 16 \\
\hline Total & 200 & 100 \\
\hline
\end{tabular}

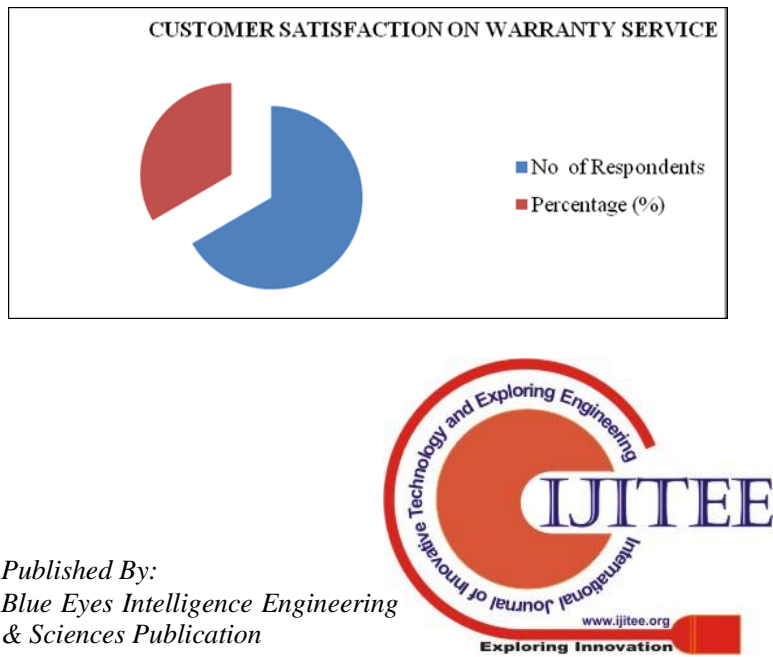




\section{Inference}

It is clear that the above table that $84 \%$ of the respondents is satisfied with the warranty service of their vehicles and only $16 \%$ of them are dis-satisfied.

Opinion on spares availability

\begin{tabular}{|l|c|c|}
\hline \multicolumn{1}{|c|}{ Ratings } & $\begin{array}{c}\text { No of } \\
\text { Respondents }\end{array}$ & $\begin{array}{c}\text { Percentage } \\
(\%)\end{array}$ \\
\hline Good & 144 & 72 \\
\hline Average & 36 & 18 \\
\hline $\begin{array}{l}\text { Below } \\
\text { Average }\end{array}$ & 16 & 8 \\
\hline Poor & 4 & 2 \\
\hline Total & 200 & 100 \\
\hline
\end{tabular}

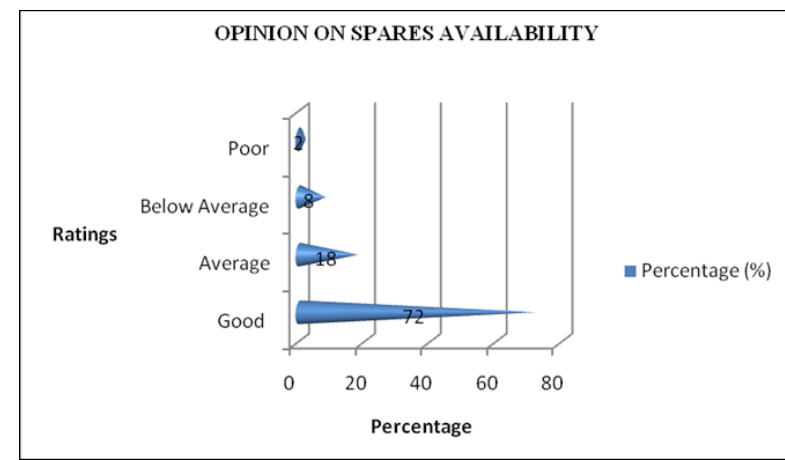

\section{Inference}

The above table shows that $72 \%$ of the respondents considered the availability of spares as good and $18 \%$ of them considered as average and only $10 \%$ of the respondents think that the availability is below average and poor.

\section{FINDINGS}

1. Among the total samples more than $74 \%$ of the customers belong to the category of employees and business.

2. Nearly $88.5 \%$ of the respondents are satisfied with Hero vehicles.

3. $84 \%$ of the respondents provided a positive response regarding the warranty service provided by the dealer.

4. Most of the respondents think that the spare parts of Hero two wheelers are readily available.

5. Majority of the respondents are influenced through advertisements which is followed by family member's, friends influences and individual decisions.

\section{CONCLUSION}

There is always a need for developing new and successful aspects. This situation can be improved with better understanding of the attitudes of the customers through frequent feedback. It will improve the loyalty as well as new attraction of customers thereby benefiting the company in the long run. Consumer contests can be considered to further the customer relationships . advertisements is the effective media to recall HERO among the people with the purchase of two-wheelers. The study concludes that HERO shows maximum satisfaction is respect to Mileage, Power, Design, Technology and After Sales Service whereas compare to others.

\section{REFERENCES}

1. Philip Kotler 2000/e- Marketing Management

2. G.C. Beri- Marketing Research

3. Aaker Myers "Advertising Management" prentice Hall of India pvt. Ltd, New Delhi.

4. Kothari. C.R,(1998).”Research Methodology", H.S Poplai for WishwaPrakashan, New Delhi.

5. Philip Kotler., Grey Amstrong.,(1999) "Principles of Marketing", AshokeK.Ghose., New Delhi.

6. PhilipKotler.,(1999) "Marketing Management" AshokeK.Ghosh., New Delhi.

7. R.S.N. Pillai\&Bagavathi., Management" S. chand\& Co. Ltd,

(1999)“Marketing

8. Rajan Nair.,(1997) "Marketing" Sultan chands\& sons, New Delhi,

9. S.A.Sherlekar,"Modern Marketing"Himalaya publishing House, Bombay.

10. Dr.C.Annandan\&M.Prasanna Mohan Raj \&Mr.S.Madhu, A Study on Brand preference of washing soaps in rural areas, Indian Journal of marketing,March2007, Page no30

11. Dr.N.Chandrasekaran, Consumer Behaviour and Brand Preference towards Onida Television -An Empirical Study with Reference to Karur, Tamilnadu,Indian Journal of Marketing, July 2009,Page No-58

12. Dr.S.K.Sinha\&Ajay Wagh, Analysing growth of cellular telecom sector and understanding consumer's preferences and choices on the use of cell phone-Indian Journal of Marketing. Sep 2008 Page no -2

13. RachelDardis, HoracioSoberon-Ferrer, consumer's preferences for Japanese auto mobiles, Journal of consumer affairs, summer 1994

14. www.hero.com

15. www.pioneerherohonda.com

16. www.autoindia.com 